Témoigner Témoigner. Entre histoire et mémoire

Getuigen Revue pluridisciplinaire de la Fondation Auschwitz

$121 \mid 2015$

Violences radicales en scène

\title{
Interview met Dorcy Rugamba
}

Entretien avec Dorcy Rugamba

\section{Christian Biet et Dorcy Rugamba}

Traducteur : Gorik de Henau

\section{(2) OpenEdition}

Journals

Édition électronique

URL : https://journals.openedition.org/temoigner/3323

DOI : 10.4000/temoigner.3323

ISSN : 2506-6390

Cet article est une traduction de :

Entretien avec Dorcy Rugamba - URL : https://journals.openedition.org/temoigner/3309 [fr]

Éditeur :

Éditions du Centre d'études et de documentation Mémoire d'Auschwitz, Éditions Kimé

Édition imprimée

Date de publication : 1 octobre 2015

Pagination : 88-95

ISSN : 2031-4183

Référence électronique

Christian Biet et Dorcy Rugamba, «Interview met Dorcy Rugamba », Témoigner. Entre histoire et mémoire [En ligne], 121 | 2015, mis en ligne le 01 novembre 2016, consulté le 04 février 2022. URL : http://journals.openedition.org/temoigner/3323 ; DOI : https://doi.org/10.4000/temoigner.3323 


\section{Dorcy Rugamba}

$\rightarrow$ Interview door

Christian Biet

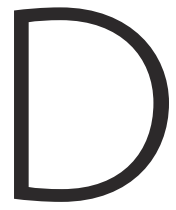

orcy Rugamba is regisseur, auteur en acteur. Hij studeerde aan het Luikse conservatorium, waar hij een eerste prijs in dramatische kunsten behaalde. In 1999 was hij coauteur van Rwanda 94, een zes uur durende voorstelling over de volkerenmoord op de Tutsi's in Rwanda (vgl. Weyssow 2014, 15); het stuk werd voor het eerst opgevoerd op het festival van Avignon door het Belgische gezelschap Groupov, in een regie van Jacques Delcuvellerie. Het ging op wereldtournee en werd in 2001 bekroond met de prijs voor het beste Belgische stuk en in 2002 met de Franse Prix de la Critique. Op initiatief van Dorcy Rugamba werd in 2001 het Rwandese kunstenaarscollectief Urwintore opgericht om de podiumkunsten in Rwanda te stimuleren en de uitwisseling tussen Rwandese en buitenlandse kunstenaars te bevorderen. In 2004 werd Dorcy Rugamba door Peter Brook gevraagd om Amkoulel te vertolken in Tierno Bokar, een vrije bewerking van Vie et enseignement de Tierno Bokar: Le sage de Bandiagara, een boek van Amadou Hampâté Ba. In 2005 publiceerde hij Marembo (Rugamba 2005) waarin hij de laatste dagen van zijn familie in Rwanda beschreef. Datzelfde jaar bewerkte en regisseerde hij L'instruction (Die Ermittlung) van Peter Weiss, dat hij achtereenvolgens bracht op het Festival Émulation in Luik, in Bouffes du Nord (Parijs), het Young Vic Theatre (Londen), het Chicago Shakespeare Theater (Chicago), het Kasser Theater (New Jersey), de Bankart Studio (Yokohama), op de Récréâtrales (Burkina Faso) en ook herhaaldelijk in Rwanda, meer bepaald in Butare en Kigali. In 2007 schreef hij en acteerde hij in Bloody Niggers, in een regie van Jacques Delcuvellerie en in coproductie met het Théâtre National en het Festival de Liège.

\section{Is het correct dat alles voor u begon met Rwanda 1994?}

Dorcy Rugamba: Nee, helemaal niet. Ik begon al heel jong met podiumkunsten in Rwanda, samen met mijn vader Cyprien Rugamba, en in 1992 richtte ik mijn eigen gezelschap Isango op. Waar ik met Rwanda 1994 echt aan begon, was theater over misdaden tegen de mensheid. Rwanda 1994 kwam vlak na de volkerenmoord tot stand, toen daar nog nauwelijks over werd gesproken. Het enige wat een Europeaan erover kon vernemen, was wat er in de media, vooral televisie, werd verteld, namelijk een vluchtig verhaal vol gemakzuchtige clichés. We maakten Rwanda 1994 omdat we vaststelden dat de kennis over de gebeurtenissen ontoereikend was, en dat ging ook op voor mezelf, nota bene een Rwandees. Via het stuk ging ik beseffen dat een groot deel van die recente geschiedenis me was ontgaan, van de eerste kolonisering (de komst van de Duitsers in 1894, daarna de Belgische voogdij en ten slotte het Franse neokolonialisme) tot de volkerenmoord honderd jaar later. 
De emotionele impact van de Cantate is helemaal anders als ze los van $R$ wanda 1994 wordt gebracht, en je er niet eerst vier uur bent op voorbereid. Dat lijkt evident, maar je kunt nog verder gaan en stellen dat het stuk ook zonder de Cantate kan bestaan.

D.R.: Het gaat om twee verschillende momenten. Het publiek van vandaag is niet hetzelfde als vijftien jaar geleden. Rwanda 1994 ging in première kort na de volkerenmoord; niet alleen waren de mensen slecht ingelicht, maar de realiteit zelf van de volkerenmoord werd in twijfel getrokken en zelfs ontkend, zowel in de media als via officiele, diplomatieke kanalen. Op dat ogenblik moest je bewijzen dat de volkerenmoord werkelijk had plaatsgevonden - een volkerenmoord en geen oorlogsmisdaad of burgeroorlog of stammenoorlog, zoals bepaalde media lieten verstaan. Tegenwoordig is die erkenning een feit, de volkerenmoord is door internationale gerechtshoven aangetoond en wordt nu officieel erkend door de Verenigde Naties. Ze is bewezen, al bestaan er inderdaad nog altijd revisionistische groepen die waarschijnlijk

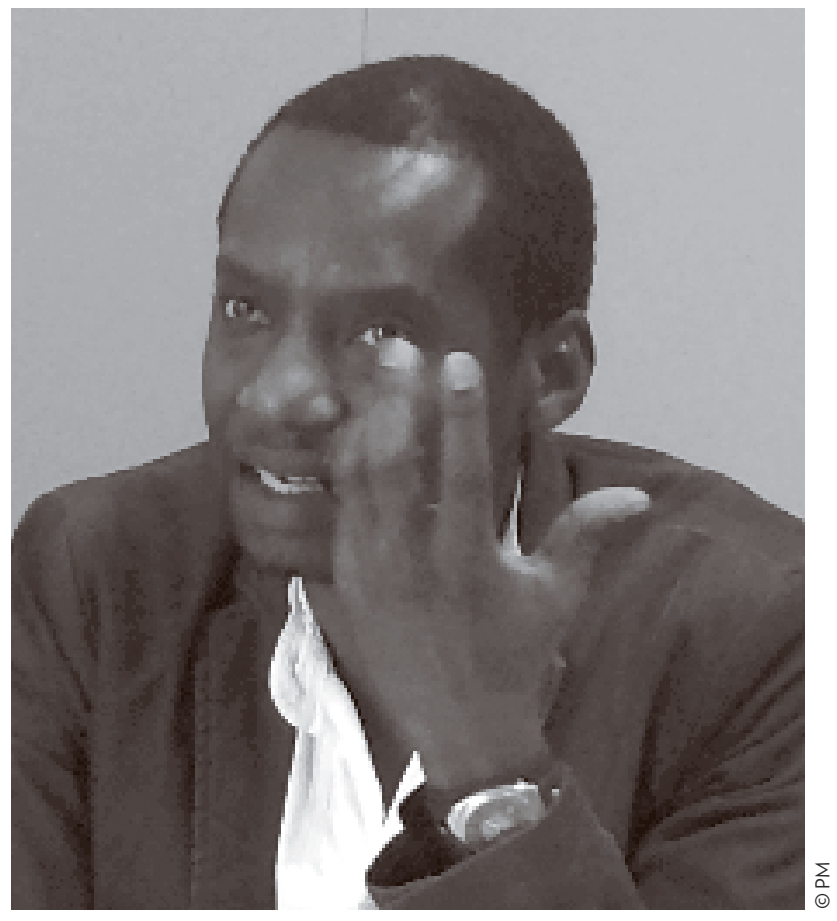
nooit zullen bijdraaien. Ondanks die revisionisten behoort de erkenning van de Rwandese volkerenmoord op de Tutsi's voortaan tot het publieke domein; ze maakt integraal deel uit van de algemene kennis. Op basis van die kennis kan het huidige publiek de Cantate dus apart beoordelen, zonder de andere, voorafgaande delen van het stuk.

\section{Hoe zou u de emotie die u nastreeft omschrijven?}

D.R.: De Cantate is van een onmiskenbare lyrische schoonheid. Het is een knap geschreven werk, zowel door de mooie tekst als door de muziek van Garret List, vertolkt door instrumenten en vrouwenstemmen. Maar het zou simplistisch zijn om het alleen als een muzikaal meesterwerk te zien. Het is geen prachtig doodskleed waarin we op vormelijke wijze de doden wikkelen. Het is ook een episch gedicht, niet alleen over de doodsstrijd van de slachtoffers van de twee Bisesero's, maar ook over de moed van die in het nauw gedreven mannen en vrouwen, die zich alleen met hun handen konden verdedigen en besloten om de rangen te sluiten en de strijd aan te gaan. De Cantate is bijna de oorlogsdaad van de Basesero-volksstam. Als zodanig speelt ze een belangrijke rol in de hele opbouw van het stuk, want een van de risico's bij het opvoeren van een volkerenmoord is dat je de slachtoffers voorstelt als lammeren die zich gewillig naar de slachtbank laten leiden. Het motto van Rwanda 94 is 'een symbolische schadeloosstelling van de doden ten voordele van de levenden'. 
Dorcy Rugamba (vervolg)
Die symbolische dimensie is voor de overlevenden natuurlijk belangrijk. Want als ze aan de verschrikking zijn ontsnapt moeten ze niet alleen trachten om weer gezond te worden en een menswaardig leven te gaan leiden, maar hebben ze ook moreel en symbolisch eerherstel nodig. De Cantate is een waardig verhaal, zoals er ook waardige beelden van de volkerenmoord bestaan, in tegenstelling tot de campagnes van hulporganisaties waarin de nadruk op ellende ligt. Bij waardige beelden denk ik bijvoorbeeld aan Les hommes debout van de Zuid-Afrikaanse kunstenaar Bruce Clarke (vgl. Korman 2014, 186).

Een van de verdiensten van de Cantate houdt verband met de vertolking. De tekst wordt door een koor gebracht, waarvan de meeste leden geen Rwandezen zijn, maar Europeanen. Ze geven nochtans gestalte aan de slachtoffers en drukken zich in hun naam uit, in de eerste persoon enkelvoud. Ze zeggen: 'Op deze dag bevond ik me op gene plek op de Muyira-heuvel.' Het gaat hier dus niet om een realistische theaterconventie. Zo kun je het drama universeel maken; het wordt letterlijk een misdaad tegen de mensheid.

\section{Als u documentair theater maakt of een ander soort theater, bijvoorbeeld Bloody Niggers, wat onthoudt u dan van uw Rwanda 1994-ervaring? \\ D.R.: Precies dat kooraspect. Een koor is een collectief dat zich uitdrukt. Een volkerenmoord treft de gemeenschap, het is een misdaad waarbij miljoenen mensen omkomen. Ze overstijgt het drama van één mens en net op dat moment verschijnt het koor, althans in een opvoering op de planken.}

Het komt er dus op neer, om te vermijden dat je een nummer bent dat zal worden afgeslacht, dat je je niet als individu moet verzetten, maar als onderdeel van een koor, dat wil zeggen als onderdeel van een systeem dat zich verzet door zijn structuur zelf. Dat doet me denken aan de keuzes die Primo Levi maakt in de toneelbewerking van Is dit een mens (Levi 2007). Hoe reconstrueerde u die koorvorm, hoe voerde u hem op, met welke tekst?

D.R.: De koorvorm haalde ik weer boven toen ik L'instruction van Peter Weiss ensceneerde. Ik koos voor Weiss' stuk toen in Rwanda de gacaca-rechtbanken van start gingen. De gacaca zijn Rwandese volksrechtbanken die tien jaar na de volkerenmoord werden opgezet om de gevangenissen te ontlasten.

Bijzonder aan de gacaca-rechtbanken is dat ze worden georganiseerd op de plek van de misdaad en dat alle plaatselijke bewoners worden uitgenodigd om eraan deel te nemen. De rechters zijn door de gemeenschap gekozen burgers, en de getuigen en beklaagden drukken zich ongekunsteld uit, zonder de filter van een jurist. Het is het ene woord tegen het andere, in het bijzijn van de jury en de verzamelde bewoners. Toen ik een gacaca-proces bijwoonde, werd ik meteen getroffen door het feit dat iedereen erbij betrokken was. Slachtoffers, beklaagden, getuigen, alle bewoners werden opgeroepen om hun zeg te doen over de feiten, om moreel onbesproken personen uit te kiezen voor de rechtspraak. In die grote santenkraam en dat vrijuit spreken zag ik de mogelijkheid van een soort theater. Er speelde zich 


\section{EXTREEM GEWELD OP/IN SCÈNE}

daar een collectief drama af, waarbij slachtoffers, beulen, getuigen, beëdigden en het gerechtshof zich in hetzelfde koor bevonden; dat alles gaf uitdrukking aan het drama van de Rwandese natie. In Butare bijvoorbeeld vonden de gacaca op woensdag plaats. Op de andere dagen van de week gedroegen de mensen zich allemaal op dezelfde manier, hielden zich met dezelfde zaken bezig en vertoonden hetzelfde gedrag, zonder dat je een onderscheid kon maken tussen wie zich op de dag van het proces in de beklaagdenbank zou bevinden, wie lid zou zijn van het hof en wie door een getuige zou worden beschuldigd. Het ging dus om een collectief met een eigen identiteit, die op het moment van het proces door de koorvorm in verschillende stemmen werd opgedeeld. En in die opdeling kwam de volkerenmoord net in zijn volledige dimensie tot uiting. In toneeltermen kon niets het collectieve drama van de Rwandese natie beter weergeven dan dit opbrekende koor tijdens de gacaca.

De reden waarom ik voor L'instruction koos, is omdat Peter Weiss' documentaire stuk ook over een nationaal drama gaat, meer bepaald over het proces in Frankfurt uit 1964. Dat was het eerste proces waarbij een Duitse rechtbank Duitsers berechtte voor misdaden die tegen andere Duitsers waren gepleegd. Onder de beklaagden en slachtoffers bevonden zich natuurlijk nog andere nationaliteiten, maar toch was het opvallend dat een land de confrontatie met zichzelf aanging. Daarin zag ik een mogelijk verband met Rwanda.

Er was nog een andere reden waarom ik voor L'instruction koos, en dan vooral met Rwandese acteurs. Ik herinnerde me dat ik, voor de Rwandese volkerenmoord, verschillende producties over de Joodse volkerenmoord had gezien en dat die me op geen enkel moment hadden geraakt. Om het schematisch voor te stellen, voor mij ging het om een verhaal dat zich onder blanke Europeanen afspeelt, iets wat in Afrika nooit kon gebeuren. En aan die afstandelijke visie bleef ik vasthouden, ook tijdens de vier jaar voor de volkerenmoord, van 1990 tot 1994. Gedurende die jaren ging het openlijk racistische vertoog van de Hutu Power-beweging meer en meer op de naziretoriek lijken en de pogroms in het land werden steeds talrijker. Ik verbleef toen aan de National University of Rwanda in Butare, maar op geen enkel moment werd er een verband gelegd tussen onze eigen situatie en wat zich in de jaren dertig in Europa had afgespeeld, met als eindpunt de volkerenmoord op Joden en Roma.

Zou het kunnen dat jullie door het uitzonderlijke karakter van de Joodse volkerenmoord niet zagen wat jullie te wachten stond?

D.R.: In de wijze waarop het mij werd voorgesteld woog de context veel meer door dan het misdadige mechanisme van de volkerenmoord zelf, en dat zorgde voor afstand. Op die manier werd het moeilijker om de volkerenmoord te begrijpen als een politiek project, als een ideologische misdaad. Vooral de beulen zagen er uit als heel andere mensen, alsof volkerenmoord een typisch Duitse misdaad was. Daardoor kwam ik op het idee de volkerenmoord op niet-naturalistische wijze op te voeren, dat leek me boeiend. Ik vond dat je zo meer licht kon werpen op de volkerenmoord als politiek project en als ideologische misdaad. Daarom zijn alle acteurs in de productie Rwandezen, hoewel ze Europese personages vertolken. De vertolker bevindt 
Dorcy Rugamba (vervolg) zich hier natuurlijk in een toestand van vervreemding. Hij is iemand die een verhaal vertelt. De toeschouwer ziet geen Duitser en ook geen typische Afrikaan. Het personage zit niet vast aan een etnische identiteit.

\section{Is het correct dat in het stuk alle acteurs op één na onderling verwisselbare rollen spelen? \\ D.R.: Precies, allemaal op één na. Om de nadruk te leggen op de collectieve dimen-} sie van het drama, maar ook om andere redenen bleek het noodzakelijk om de tekst aan te passen, met een vorm die dichter bij de antieke tragedie lag en met een koor en koorleider. Het lezen van Peter Weiss' oorspronkelijke tekst neemt vijf uur in beslag. Het is een verbatim-stuk dat Weiss in elf secties verdeelde, in een structuur die teruggaat op het Inferno van Dante. De tekst wordt steeds gruwelijker en we zijn getuige van de opeenvolgende vernietigingsmethoden die de SS in Auschwitz uitprobeerde; bij elke stap gaat het steeds extremer, alsof we afdalen in de hel, tot en met de Endlösung. Het werk van Dante mag in Europa dan bekend zijn, in Rwanda is het dat niet. Op vormelijk vlak moesten we iets anders vinden, iets dat verwant was aan de plaatselijke toneelpraktijk. Om de tekst in te korten hanteerden we ook een ander criterium. Voor veel getuigen op het proces in Frankfurt in 1964 was het de eerste maal dat ze vertelden wat hen was overkomen. De publieke opinie had geen flauw idee van wat er zich werkelijk in de vernietigingskampen had afgespeeld. Bovendien bulkt Weiss' stuk van de precieze details, als in een regelrecht juridisch onderzoek, in die mate dat de toeschouwer aan het eind van het stuk niet de minste twijfel meer heeft over de realiteit van de volkerenmoord. De lange tekst was uitgerekend op dat historische moment van belang, omdat hij het bewijs van de volkerenmoord leverde via de uitspraken van moordenaars, slachtoffers en eersterangs getuigen zoals leden van het Sonderkommando. Twintig jaar na de volkerenmoord was die vermenging van stemmen cruciaal, maar vandaag liggen de zaken anders. Het publiek dat komt kijken naar een opvoering van Weiss' L'instruction weet dat er een volkerenmoord heeft plaatsgevonden, je hoeft geen bewijsmateriaal meer aan te voeren. Maar, en op dit vlak bleek een bewerking noodzakelijk, hoe meer mensen feitenkennis hebben van de volkerenmoord op de Joden, hoe minder ze er empirische kennis van hebben. En dus hoe minder mensen daadwerkelijk beseffen wat een volkerenmoord inhoudt, wat voor een misdaad het is en waarin ze van andere moorden verschilt. We waren dus vastbesloten om de kijker met de bewerking en de regie te informeren over de aard van de misdaad. Via de woorden van kampoverlevenden wilden we te verstaan geven wat een daad van vernietiging inhoudt en het publiek met de woorden van de beklaagden in de rechtszaal duidelijk maken waar een ideologische misdaad op slaat. Hoe verklaart de moordenaar zijn daad, hoe rechtvaardigt hij die op zijn manier? Zo krijg je zicht op de misdaad. De acteurs vermijden een botte geweldenaar te maken van de misdadiger, of hem karikaturaal voor te stellen. Misschien is hij wel een goede huisvader, wie weet? Wat ons boeit, is wat er in zijn hoofd omgaat, wat zijn gedrag motiveert en wat we daaruit kunnen leren... 


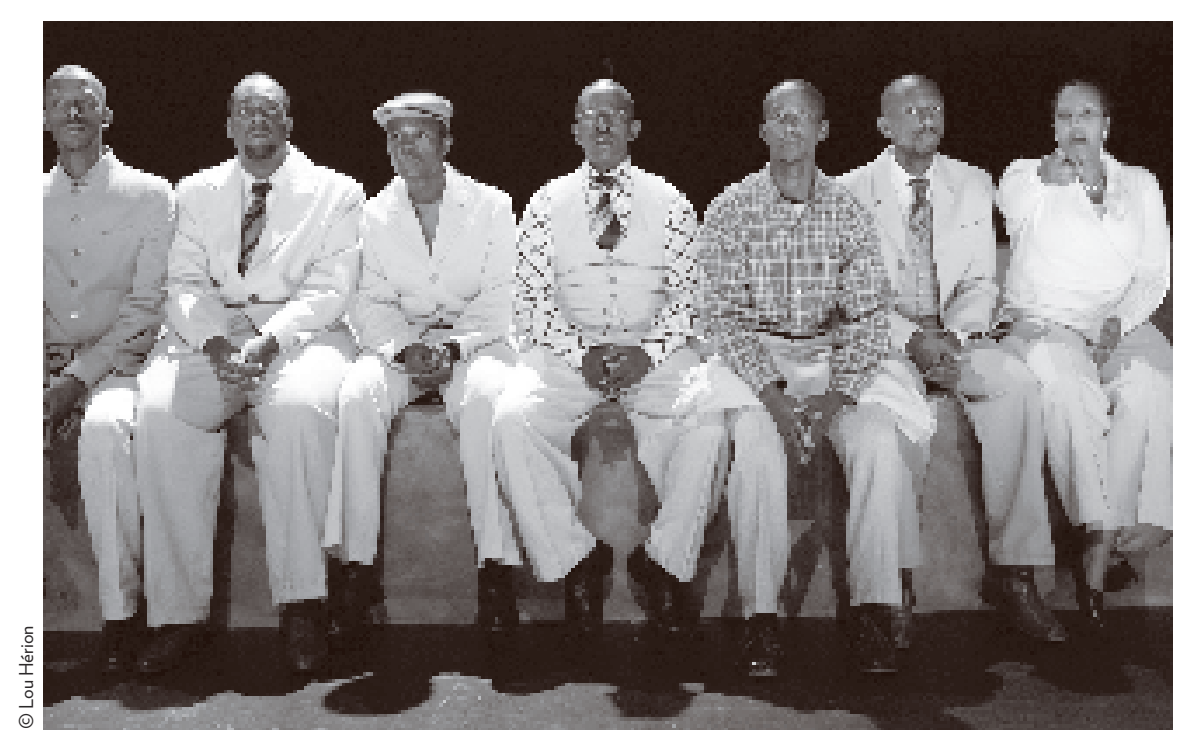

Indrukwekkend aan het stuk is dat u de vraag naar wat er in het hoofd van de beulen omgaat naar de slachtoffers verlegt. Hoe kreeg dit vorm in het schrijven en de regie?

D.R.: Dankzij het juridische onderzoek ontsnappen we aan een manier van schrijven en een regie waardoor het geheel zou gaan lijken op een plechtstatige mis waarin de misdaad op morele gronden wordt veroordeeld. Via het onderzoek kunnen we alle partijen aan het woord laten. Ik tracht me altijd in de positie van de toeschouwer te verplaatsen en stel mezelf de vraag: als iemand me de les zou lezen, zou ik dat aanvaarden of niet? Het is belangrijk dat de toeschouwers tijdens de kijkervaring hun oordeelsvermogen kunnen aanspreken. Onder Weiss' beklaagden bevindt zich een verdachte, Starck, die op het moment van de feiten nog heel jong was, een SS'er afkomstig uit de Hitlerjugend. In het kamp hield Starck zich onder meer bezig met het selecteren van de gedetineerden op het perron waar de treinen aankwamen; hij verdeelde hen in drie categorieën, namelijk gevangenen van gemeen recht, politieke en raciale gevangenen. Op de vraag van de rechter: 'Vond u het normaal om vrouwen en kinderen naar de gaskamers te sturen?', antwoordt Starck: 'Ja. Er gold toen een principe van gedeelde rassenverantwoordelijkheid.' Met die repliek van de moordenaar krijgt de toeschouwer een beter begrip van de afgrijselijke misdaad dan met de simpele formulering 'nooit meer', want ze werpt niet alleen licht op de misdaad en de uitvoerder ervan, maar ook op de ideologie waarvan hij zich bedient.

In mijn stuk Bloody Niggers wilde ik ook dat aspect aanpakken. Ik wilde weg van het jaar 1994 in Rwanda, ik wilde een genealogie van de volkerenmoord opstellen. Welke weg legden we als mensheid af om hier uit te komen? Daartoe bracht ik verschillende misdaden tegen de mensheid weer onder de aandacht van het publiek, maar dat is niet voldoende. Wat ze in een nieuw daglicht plaatst, is de manier waarop
_Bloody Niggers, Groupov, 2007. 
Dorcy Rugamba (vervolg) hun daders ze rechtvaardigen. Je kunt bijvoorbeeld documentaires bekijken over de kolonisatie en je informeren over de vaak volledige uitroeiing van volkeren bijvoorbeeld de Tasmaniërs in de negentiende eeuw - en daardoor tot tranen toe bewogen worden, maar je begrijpt er pas werkelijk de gruwelijke dimensie van als je ontdekt hoe wijdverspreid de rechtvaardiging van die misdaden wel was. Het project werd immers ondersteund, niet door notoire ideologische racisten als Gobineau, maar door erkende en eerbiedwaardige humanistische filosofen, kerkleiders, rechtsgeleerden en wetenschappers. Via hun woorden en door het project zelf komt het buitensporige, totalitaire karakter van het koloniale imperialisme tot uiting.

Van de Rwandese volkerenmoord en de volkerenmoord op de Europese Joden stapt $u$ inderdaad over op het kolonialisme en recentelijk gaf $u$ in een commentaar op Exhibit $B$ ook uw kijk op de slavenhandel. Is er in dat geval volgens u sprake van volkerenmoord? En kan slavenhandel op de planken worden gebracht?

D.R.: In Bloody Niggers wijdde ik een heel hoofdstuk aan de handel in zwarte slaven en de driehoekshandel, die ik op één lijn stel met volkerenmoord. Want de trans-Atlantische slavenhandel verschilt van alle andere vormen van slavernij en lijfeigenschap die ooit op aarde hebben bestaan of nog bestaan. Het verschil zit opnieuw in de ideologie. In andere perioden en contreien was de slaaf een gevangene, iemand wiens vrijheid was afgenomen, maar een menselijk wezen. In de Amerikaanse koloniën werd dat menselijk statuut juridisch aangevochten in wetteksten, door wetenschappers die daarvan het bewijs trachtten te leveren, door theologen die verordenden dat de slaaf geen ziel heeft enzovoort. Concreet werd de slaaf als vee behandeld, zowel in de feiten als principieel. 'L'esclave est un bien meuble' (een slaaf is een goed meubelstuk) stelde artikel 44 van de Code noir. Het is een daad van vernietiging, waarvan de ideologische betekenis niet tot de plantages beperkt bleef en waardoor alle zwarten werden uitgesloten. Dat is natuurlijk gevoelige materie voor het theater, want zoals alle misdaden tegen de mensheid heeft de slavenhandel een spectaculaire dimensie waar je verstomd van kunt staan. Als je dat op de planken brengt, wordt het risico heel groot dat het een spektakelstuk wordt en dat de toeschouwer tegen heug en meug tot een voyeur wordt gemaakt. Naar mijn bescheiden mening is dat de valstrik waar Exhibit $B$ is ingelopen.

Precies, hoe verhoudt u zich tot de conventionele toneelvormen zoals die met name nog altijd in een aantal Franse stukken worden gehanteerd?

D.R.: Ik heb niets tegen dramatische conventies, al vind ik dat je vormelijke aspecten steeds opnieuw moet uitvinden. Ik denk echt aan het publiek, wat kunnen we hun voorstellen om geweld te begrijpen? Als je hen alleen maar gevechten en liters hemoglobine laat zien, dan ga je ervan uit dat ze geweld slechts via de meest elementaire middelen kunnen benaderen, terwijl het natuurlijk veel complexer is.

Kan je via beelden geen heftige reactie uitlokken, niet om de toeschouwer te ontstellen maar om aan te zetten tot reflectie? Ik denk met name aan het bloederige beeld van een 


\section{EXTREEM GEWELD OP/IN SCÈNE}

beul in actie. Anders gezegd, is de voyeur, die misschien zelfs een zeker plezier ervaart, werkelijk niet in staat om na te denken?

D.R.: Moeilijk te zeggen of je al dan niet zulke beelden moet tonen. De kunst van het opvoeren is een complex proces. Ik vraag me niet af wat ik mag tonen en wat niet, maar wel hoe ik dat kan doen, op welke manier, met welke middelen. Stel dat ik bijvoorbeeld besluit een verkrachtingsscène te ensceneren, iets wat in grootschalige misdaden vaak voorkomt. A priori is daar niets verkeerds mee. Maar als ik besluit om die verkrachtingsscène via de regie volop te erotiseren, dan zorg ik ervoor dat de toeschouwer het slachtoffer met dezelfde blik bekijkt als de verkrachter. Dat wil zeggen dat ik welwillend sta tegenover de misdaad, dat ik me verlustig in een daad die ik zogenaamd veroordeel. In dat geval zouden de slachtoffers zich dus met recht en rede vernederd kunnen voelen en de voorstelling als verachtelijk afdoen. Daar gaat het eigenlijk om. Als ik mezelf toesta om gewelddadige beelden te tonen, moet ik dan gebruik maken van dit soort prikkels? Het is een esthetische kwestie, en over esthetica kun je niet in absolute bewoordingen praten.

Laatste vraag: is het de taak van theater om de mechanismen van historische gebeurtenissen te onthullen en er emotie aan toe te voegen?

D.R.: Ja, natuurlijk, er moet emotie aan te pas komen. In elk geval moet theater ook zintuiglijk zijn, er moeten meer dan alleen intellectuele stimuli zijn. Je moet de toeschouwer dus trachten te vangen via de verschillende doors of perception. Theater is geen lezing, je kunt je niet tot een toespraak beperken. Theater is een ervaring, dat is echt fundamenteel voor mij. Theater moet de mechanismen achter de gebeurtenissen onthullen. Welke factoren beslissen nu precies of een bevolking ergens in meegaat?

Vertaling: Gorik de Henau

\section{BIBLIOGRAFIE}

- Rémi Korman, 'The Arts and the Representation of the Genocide of the Tutsi in Rwanda', Getuigen. Tussen geschiedenis en herinnering 119, 2014, 184-186.

- Primo Levi, Is dit een mens, vertaald uit het Italiaans door Frida De Matteis-Vogels, Amsterdam: Meulenhoff, 2007.

- Dorcy Ingeli Rugamba, Marembo, Parijs: Da Ti M’Beti, 2005.

- Daniel Weyssow, 'Rwanda 94. Une tentative de réparation symbolique envers les morts', Témoigner entre histoire et mémoire 117, 2014. 